\title{
Identification of a single nucleotide polymorphism showing no insulin-mediated suppression of the promoter activity in the human insulin receptor substrate 2 gene
}

\author{
K. Iwamoto, H. Mori, H. Okazawa, M. Hashiramoto, M. Kasuga \\ Division of Diabetes, Digestive and Kidney Diseases, Department of Clinical Molecular Medicine, Kobe University, Japan
}

\begin{abstract}
Aims/hypothesis. To understand the transcriptional regulation and to investigate the pathological influence upon Type II (non-insulin-dependent) diabetes mellitus of insulin receptor substrate 2 (IRS2), the $5^{\prime}$ flanking region of the human IRS 2 gene was cloned and screened in Japanese diabetic patients.

Methods. Luciferase reporter assay and electrophoretic mobility shift assay (EMSA) were combined in HepG2, Fao, RINm5F, and HeLa cells to characterise the human IRS2 promoter region. Single nucleotide polymorphisms (SNPs) were identified in Japanese Type II diabetic patients by sequencing and were genotyped.

Results. The proximal 2399 bp of the 5' flanking region of the human IRS 2 gene was cloned. A core promoter region was extended between nucleotide positions -834 and -557 (relative to the translation initiation site). The region [(-758)AGGGGGAGGG(-749)] that appears important in the positive regulation of
\end{abstract}

Received: 29 January 2002 / Revised: 17 April 2002

Published online: 19 June 2002

(C) Springer-Verlag 2002

Corresponding author: M. Hashiramoto, MD, PhD, Division of Diabetes, Digestive and Kidney Diseases, Department of Clinical Molecular Medicine, Kobe University Graduate School of Medicine, 7-5-1 Kusunoki-Cho, Chuo-Ku, Kobe 650-0017, Japan. E-mail: hashira@med.kobe-u.ac.jp

Abbreviations: IRS, Insulin receptor substrate; IR, insulin receptor; PI3K, phosphatidylinositol 3-kinase; DM, diabetes mellitus; nt, nucleotide; PCR, polymerase chain reaction; DTT, dithiothreitol; EMSA, electrophoretic mobility-shift analysis; UV, ultraviolet; PAGE, polyacrylamide gel electrophoresis; C/EBP CCAAT, enhancer binding protein; HNF3, hepatocyte nuclear factor 3; MZF1, myeloid zinc finger protein 1; HSF, heat shock factor; GKLF, gut Krüppel-like factor; RFLP, restriction fragment length polymorphism analysis; SNP, single nucleotide polymorphism; IRE, insulin responsive element; UTR, untranslated region; ANCOVA, analysis of covariance.
IRS 2 transcription was identified by EMSA with ${ }^{32} \mathrm{P}-$ labelled double-stranded oligonucleotides encompassing regions protected from DNase I digestion by nuclear extract of HepG2 cells. Two SNPs $(-765 C / T$ and $-2062 T / C$ ), identified by screening Japanese Type II diabetic patients, were not associated with Type II diabetes. IRS2-driven reporter activity in the plasmid containing thymine at -765 was not suppressed by insulin when measured in Fao cells.

Conclusion/interpretation. The $5^{\prime}$ flanking sequence of the human IRS2 was investigated and two SNPs were identified. The SNP at -765 was suggested to be involved in the insulin-mediated regulation of the transcriptional activity of IRS2. [Diabetologia (2002) 45:1182-1195]

Keywords Insulin receptor substrate 2, promoter, transcription, luciferase assay, insulin, Fao, insulinresponsive element, Type II diabetes, genetics, single nucleotide polymorphism.

The insulin receptor substrate (IRS) proteins are phosphorylated by the insulin receptor (IR) and mediate the actions of insulin by acting as adapter or scaffolding molecules [1]. To date, four IRS proteins (IRS1 to IRS4) have been identified, all of which possess a conserved domain structure that includes pleckstrin homology and phosphotyrosine-binding domains in the $\mathrm{NH}_{2}$-terminal region $[2,3,4,5,6]$. The $\mathrm{COOH}$ terminal region of these proteins is poorly conserved, with the exception of the presence of multiple motifs that undergo tyrosine phosphorylation in response to insulin and serve as docking sites for Src homology 2 domain-containing proteins, such as phosphatidylinositol 3-kinase (PI3K), SH2 domain-containing phosphotyrosine phosphatase (SHP2), and Grb2. These motifs are therefore thought to mediate most IR downstream signalling events that cause insulin action. 
IRS1 mediates several cellular responses to insulin stimulation, including mitogenesis, protein synthesis, and glucose transport [1]. Mice deficient in IRS1 show marked growth retardation, mild insulin resistance with normal basal glucose concentrations and fasting hyperinsulinaemia, and an increased beta-cell mass $[7,8,9,10]$ but they do not develop diabetes. In addition, although variants of the human IRS1 gene have been detected, these mutations account for disease in only a small proportion of patients with Type II (non-insulin-dependent) diabetes mellitus [11, 12].

IRS2 was initially discovered as an interleukin-4 receptor substrate and was subsequently shown to be an IRS that was phosphorylated in cells from IRS1deficient mice [13]. It has been suggested that insulin resistance induced by IRS1 deficiency can be compensated for by IRS 2 and increased insulin production, thereby explaining the non-diabetic phenotype of IRS1 knockout mice [1]. Homozygous disruption of the IRS 2 gene in mice results in progressive deterioration of glucose homeostasis, characterised by an increase in fasting hyperglycaemia, and overt diabetes [9]. Morphometric analysis of the pancreatic islets of these mice showed a marked reduction in beta-cell mass, which prevents an increase in the concentration of insulin secretion sufficient to compensate for the insulin resistance. These observations suggested that functional defects in IRS 2 could contribute to Type II diabetes by impairing insulin production (through effects on beta-cell neogenesis, proliferation, or survival) and insulin action.

Nucleotide substitutions have been detected in the coding region of the human IRS 2 gene $[14,15,16]$. Among them, only the Gly ${ }^{1057} \rightarrow$ Asp is predicted to contribute to the prevalence of Type II diabetes mellitus since Asp ${ }^{1057}$ carriers can have higher insulin sensitivity [16]. Given that genetic variability in promoter sequences potentially affects the level of protein expression, the organisation and $5^{\prime}$ flanking sequence of human IRS2 were recently examined [15, 17, 18]. However, the promoter sequence described was only partial and the genetic variability of this sequence in diabetic subjects was not intensively investigated.

We therefore designed our studies to sequence and characterise the $5^{\prime}$ untranslated region (UTR) of the human IRS2 gene and to screen this region for mutations in Japanese diabetic patients. We also investigated the potential mechanism for the insulin-mediated repression of the IRS 2 gene by using the polymorphisms which were identified.

\section{Subjects and methods}

Cloning of the human IRS2 gene. Two DNA fragments encompassing the protein-coding region of human IRS2 [nucleotides (nt) 73 to 395 and 3537 to 3992] were obtained by polymerase chain reaction (PCR) amplification with a human placental genomic DNA library (Clontech, Palo Alto, Calif., USA) as tem- plate and two pairs of primers [5'-aacaacaacaaccacagcgtc-3' (forward) and $5^{\prime}$-tcctgctcctgctcgttctc-3' (reverse); 5' -tgtctctctcaggaaaagcag-3' (forward) and $5^{\prime}$-ttcaagtggtgggacaagaag- $3^{\prime}$ (reverse), respectively, based on the gene sequence in GeneBank (accession no. AB000732)]. These fragments were then used as probes to screen the same genomic library for human IRS2. Three clones that initially tested positive with both probes were confirmed to be derived from human IRS 2 by Southern blot analysis, and were subcloned into the pBluescript II KS(+) vector (Stratagene, La Jolla, Calif., USA) and sequenced with an ABI PRISM 377 DNA sequencing system (Perkin Elmer, Norwalk, Conn., USA). Transcription factor binding sites were analysed with Transcription Factor Search (TFSEARCH) [19, 20].

Generation of luciferase reporter constructs. The transcriptional activity of the human IRS2 promoter was analysed with the use of the promoterless luciferase expression plasmid pGL3-Basic (Promega, Madison, Wis., USA). A 2.6-kb fragment of the promoter (nt -2399 to +217 ) was isolated from human IRS 2 by digestion with XhoI and inserted into the XhoI site of pBluescript II KS(+), thereby generating pBS-5'hIRS2. An initial series of deletion constructs corresponding to specific portions of the cloned 5' UTR was generated with the use of available restriction sites and subcloning into equivalent sites. The largest fragment of the promoter sequence ( $n t-2399$ to -124) was obtained by digestion of $\mathrm{pBS}-5^{\prime}$ hIRS2 with SacI [site located in the multiple cloning region of pBluescript II $\mathrm{KS}(+)$, upstream from the IRS2 sequence] and MluI (site located at nt -124 of IRS2), and was subcloned into the corresponding sites of pGL3-Basic. The resultant plasmid, which contained the promoter in the correct orientation, was designated pGL3-IRS2(-2399).

To generate pGL3-IRS2(-1824), we first subcloned an $\sim 2$ - kb EcoRI-XhoI fragment of the promoter $(-1824$ to +217$)$ into the EcoRI and XhoI sites of pBluescript II $\mathrm{KS}(+)$; the SacI-MluI fragment of the resulting construct was then excised and ligated into the SacI and MluI sites of pGL3-Basic. To construct pGL3-IRS2(-2116), we amplified $\sim 300$-bp DNA fragments by PCR with pBS-5'hIRS2 as template, a forward primer (5'-TTCTATGAATTCTAGAGGACATC-3'), and a reverse primer $\left(5^{\prime}\right.$-TGCTTCGAATTCATGTATCTAC T-3'); the forward primer introduced a mutation that created an EcoRI site that permitted the direct subcloning of this fragment. The resulting PCR product was digested with EcoRI, purified with a QIAquick PCR purification kit (Qiagen, Valencia, Calif., USA), and subcloned into the EcoRI site of pGL3-IRS2 $(-1824)$.

For the construction of pGL3-IRS2(-1572) and pGL3IRS2(-269), pBS-5'hIRS2 was digested with PstI [sites located in the multiple cloning region of pBluescript II $\mathrm{KS}(+)$, upstream of the IRS 2 promoter, and at nt -1572 of IRS2] or NotI [sites located in the multiple cloning region of pBluescript II $\mathrm{KS}(+)$, upstream of the IRS2 sequence, and at nt -269 of IRS2] to remove the $5^{\prime}$ flanking sequence upstream of $\mathrm{nt}-1572$ and -269 , respectively. The remaining sequences were self-ligated and then digested with SacI and MluI and the resulting fragments were inserted into the SacI-MluI sites of pGL3-Basic.

The constructs pGL3-IRS2(-1232), pGL3-IRS2(-834), and pGL3-IRS2(-556) were generated by digestion of pBS5'hIRS2 with EcoRV [site located in the multiple cloning region of pBluescript II $\mathrm{KS}(+)$, upstream from the IRS2 promoter] and either NruI, NaeI, or SapI (sites located within the IRS2 sequence), respectively. The remaining sequences were self-ligated and then digested with SacI and MluI and the resulting fragments were ligated into SacI-digested and MluIdigested pGL3-Basic. 
A second series of deletion constructs was generated by PCR amplification of DNA fragments spanning nt $-786,-743$, $-674,-635$, or -600 to -124 with pGL3-IRS2 $(-1232)$ as template, five different forward primers (5'-CCCGAGCTCGCCCGGC-3'， 5'-GAGGGGAGCTCGGGAAAC-3'， 5'-AGCGGAGCTCCGATTGGC-3', 5'-GGCGGAGCTCCAATGCG-3', and 5'-GGCCGAGCTCTGTGTGC-3', respectively), and a common reverse primer (5'-CCCGATCACGCGTCCCT-3'); each of the forward primers introduced a mutation to create a SacI site that facilitated the subcloning of these fragments. The resultant PCR products were digested with SacI and MluI, purified with a QIAquick PCR purification kit, and ligated into the corresponding sites of pGL3-Basic, yielding the plasmids pGL3-IRS2(-786), pGL3-IRS2(-743), pGL3-IRS2 (-674), pGL3-IRS2(-635), and pGL3-IRS2(-600), respectively.

In vitro mutagenesis was done with a Quikchange SiteDirected Mutagenesis Kit (Stratagene), the pGL3-IRS2(-834) plasmid as template, and the following oligonucleotides $(\mathrm{mu}-$ tated sequences underlined) that disrupted protein binding at specific sites in the identified footprint regions: footprint 1 , GGCCTCCGCGGAAAGGGGAAAGGACGGCGGGAAAC; footprint 2, GGGGAGAAAGGGGTTCGGTTCGGGTTCGCGCGGCCCGCCC, an insulin responsive element (IRE): CGCCGAGTCACATGTTGCCTTGCTCTTCTTAG, and an identified SNP at nt -765 of IRS2, substituting $\mathrm{C}$ to $\mathrm{T}$ : CGGGCCGGGGCCTTCGCGGGAGGGGGA. The latter two plasmids generated were designated pGL3-IRS2-mutIRE and pGL3-IRS2(-765T), respectively. The orientation and sequence of all constructs were verified by direct sequencing.

Transient transfection of cultured cells and assay of luciferase activity. Plasmids used for transfection were purified with a Qiagen plasmid kit after phenol-chloroform precipitation. HepG2, Fao, RINm5F and HeLa (RIKEN, Tsukuba, Japan) cells were grown under an atmosphere of $5 \% \mathrm{CO}_{2}$ at $37^{\circ} \mathrm{C}$ in DMEM supplemented with $10 \%$ foetal bovine serum, $2 \mathrm{mmol} / \mathrm{l}$ L-glutamate, penicillin (100 U/l), and streptomycin $(100 \mathrm{mg} / \mathrm{l})$. The day before transfection, cells were transferred to six-well culture dishes at a density that ensured that they would achieve 70 to $80 \%$ confluence by the time of transfection. Cells were transfected with $1 \mu \mathrm{g}$ of luciferase reporter construct DNA and $100 \mathrm{ng}$ of the internal control plasmid pRL-TK (Promega) with the use of FUGENE 6 (Roche, Indianapolis, Ind., USA). For the experiments in Fig. 7, the medium was replaced with serum-free DMEM $8 \mathrm{~h}$ after transfection and incubated for $16 \mathrm{~h}$ to establish a basal condition followed by additional incubation in the absence or presence of $10^{-7} \mathrm{~mol} / \mathrm{l}$ insulin for $16 \mathrm{~h}$. At 40 $\mathrm{h}$ after transfection, the culture medium was removed and the cells were washed with a phosphate-buffered saline solution [137 mmol/l NaCl, $2.7 \mathrm{mmol} / \mathrm{l} \mathrm{KCl}, 1.5 \mathrm{mmol} / \mathrm{l} \mathrm{KH}_{2} \mathrm{PO}_{4}$, $\left.8.0 \mathrm{mmol} / \mathrm{L} \mathrm{Na}_{2} \mathrm{HPO}_{4}(\mathrm{pH} 7.4)\right]$. Lysis buffer $(500 \mu \mathrm{l})$ provided with the Dual-Luciferase Reporter Assay System (Promega) was added to each well and the culture plates were gently agitated for $30 \mathrm{~min}$ at room temperature. The cell lysates were then transferred to microfuge tubes and centrifuged at $12000 \times \mathrm{g}$ for $3 \mathrm{~min}$, after which the resulting supernatants were assayed sequentially for firefly and Renilla luciferase activities with the Dual-Luciferase Reporter Assay System (Promega) and a 1253 Luminometer (Bio-Orbit, Turku, Finland). The activity of Renilla luciferase, expressed from the pRL-TK plasmid under the control of the thymidine kinase promoter, provided an internal control to monitor transfection efficiency. The firefly luciferase activity was thus normalised on the basis of Renilla luciferase activity.

Preparation of nuclear extracts. Nuclear extracts were prepared from HepG2 or Fao cells as described [21] with minor modifications. In brief, cells were rinsed with and scraped into phosphate-buffered saline and then isolated by centrifugation at $1500 \times \mathrm{g}$ for $5 \mathrm{~min}$. The resulting pellet was resuspended in a solution containing $10 \mathrm{mmol} / \mathrm{l}$ HEPES-KOH ( $\mathrm{pH} 7.9)$, $10 \mathrm{mmol} / 1 \mathrm{KCl}, 0.1 \mathrm{mmol} / \mathrm{l}$ EDTA, $0.1 \mathrm{mmol} / \mathrm{l}$ EGTA, $1 \mathrm{mmol} / \mathrm{l}$ dithiothreitol (DTT) and $0.5 \mathrm{mmol} / \mathrm{l}$ phenylmethylsulfonyl fluoride. Nonidet P-40 (Nacalitesque, Kyoto, Japan) was then added to the cells on ice to a final concentration of $0.5 \%$, and the tube was mixed vigorously for $30 \mathrm{~s}$. The nuclei were separated by centrifugation and extracted with a solution containing $50 \mathrm{mmol} / \mathrm{l} \mathrm{HEPES}-\mathrm{KOH}$ (pH 7.9), $420 \mathrm{mmol} / \mathrm{l} \mathrm{KCl}$, $5 \mathrm{mmol} / \mathrm{l} \mathrm{MgCl} 2,0.1 \mathrm{mmol} / 1$ EDTA, $1 \mathrm{mmol} / 1$ DTT, $20 \%$ glycerol and $0.5 \mathrm{mmol} / \mathrm{l}$ phenylmethylsulfonyl fluoride. The concentration of the nuclear extract was measured with a protein assay reagent (BioRad, Hercules, Calif., USA).

DNase I footprint analysis. A DNA fragment (nt -1102 to -611) was obtained by digesting pGL3-IRS2(-1232) with NotI and treated with calf intestinal alkaline phosphatase (TAKARA, Otsu, Japan). The released oligonucleotide was isolated by gel electrophoresis and 5'-end-labelled with the use of T4 polynucleotide kinase (TAKARA) and $\left[\gamma-{ }^{32} \mathrm{P}\right]$ ATP (ICN, Costa Mesa, Calif., USA). The labelled DNA was digested with ApaI to remove the 196-bp DNA from the distal end of the IRS2 promoter sequence. The resulting DNA fragment thus labelled only at the proximal end (corresponding to nt -906 to -611 of IRS2) was gel-extracted and purified with the use of a QIAGEN Kit (Qiagen).

The purified double-stranded probe (10 ng, 30 $000 \mathrm{cpm})$ was incubated at room temperature for $30 \mathrm{~min}$ with $30 \mu \mathrm{g}$ of HepG2 nuclear extract in a volume of $50 \mu$ l containing $4 \mu \mathrm{g}$ of poly $(\mathrm{dI}-\mathrm{dC}) \cdot$ poly $(\mathrm{dI}-\mathrm{dC})$ (Amersham Pharmacia Biotech, Little Chalfont, UK), $1.25 \mu \mathrm{g}$ of salmon testis DNA, $10 \mathrm{mmol} / \mathrm{l}$ HEPES-KOH (pH 7.9), $80 \mathrm{mmol} / \mathrm{l} \mathrm{KCl}, 5 \mathrm{mmol} / \mathrm{l} \mathrm{MgCl}_{2}$, $1 \mathrm{mmol} / \mathrm{l}$ EDTA, $0.5 \mathrm{mmol} / \mathrm{l} \mathrm{DTT}$, and $4 \%$ glycerol. After adding $5 \mu \mathrm{l}$ of a solution containing $5 \mathrm{mmol} / \mathrm{l} \mathrm{CaCl}_{2}$ and $10 \mathrm{mmol} / \mathrm{l} \mathrm{MgCl}_{2}$, the mixture was incubated for an additional $1 \mathrm{~min}$ at room temperature. DNase I (0.35 U) (Amersham Pharmacia Biotech) was then added to the reaction mixture and incubation was continued for an additional $1 \mathrm{~min}$ at room temperature. The reaction was terminated by adding $140 \mu \mathrm{l}$ of a solution containing $190 \mathrm{mmol} / \mathrm{l}$ sodium acetate, $30 \mathrm{mmol} / \mathrm{l}$ EDTA, $0.14 \%$ SDS, and yeast tRNA $(64 \mu \mathrm{g} / \mathrm{ml})$. After the addition of $5 \mathrm{U}$ of proteinase $\mathrm{K}$ (Wako, Osaka, Japan) and incubation for $30 \mathrm{~min}$ at $50^{\circ} \mathrm{C}$, the DNase I-digested DNA was purified by phenol-chloroform extraction and ethanol precipitation and then subjected to electrophoresis on a $6 \%$ polyacrylamide gel containing $8 \mathrm{~mol} / \mathrm{l}$ urea. $\mathrm{A} \mathrm{G}+\mathrm{A}$ sequencing ladder was generated by removing modified bases of the probe with $4 \%$ formic acid and subsequent cleavage with piperidine at $G$ and $\mathrm{A}$ residues.

Electrophoretic mobility-shift assay (EMSA) analysis. Oligonucleotides including the sequences for footprint 1 [(-773)CGGGGCCTCCGCGGGAGGGGGAGGGGACGGCGGGAAACG(-735)], footprint 2 [(-726)GGAGAAAGGGGGGCGGGGCGGGGGC(-702)], -765C [(-777) CGGGCCGGGGCCTCCGCGGGAGGGGGA (-751)] and -765T [(-777) CGGGCCGGGGCCTTCGCGGGAGGGGGA (-751)] of the IRS2 promoter were synthesised in both sense and antisense strands as single-stranded molecules, the corresponding pairs of which were first incubated at $85^{\circ} \mathrm{C}$ for $5 \mathrm{~min}$ in annealing buffer [20 mmol/l Tris-HCl (pH 7.5), $10 \mathrm{mmol} / 1 \mathrm{MgCl}_{2}, 50 \mathrm{mmol} / \mathrm{l}$ $\mathrm{NaCl}$ and then gradually cooled to $45^{\circ} \mathrm{C}$ to generate doublestranded DNA molecules. The double-stranded molecules were labelled with $\left[\gamma_{-}{ }^{32} \mathrm{P}\right] \mathrm{ATP}$ and used as probes in EMSA experiments. HepG2 and Fao nuclear extract ( $5 \mu \mathrm{g}$ of protein) was 
incubated for $30 \mathrm{~min}$ at room temperature with $1 \mu \mathrm{g}$ of poly $(\mathrm{dI}-\mathrm{dC}) \cdot \operatorname{poly}(\mathrm{dI}-\mathrm{dC})$ and $0.1 \mu \mathrm{g}$ of salmon testis DNA in a total volume of $20 \mu \mathrm{l}$ containing $10 \mathrm{mmol} / \mathrm{l} \mathrm{HEPES}-\mathrm{KOH}$ (pH 7.9), $50 \mathrm{mmol} / \mathrm{l} \mathrm{KCl}, 5 \mathrm{mmol} / \mathrm{MgCl}_{2}, 1 \mathrm{mmol} / \mathrm{l}$ EDTA, $0.5 \mathrm{mmol} / \mathrm{l} \mathrm{DTT}$, and $5 \%$ glycerol. After the addition of $1 \mu \mathrm{l}$ $(0.8 \mathrm{ng}, \sim 25,000 \mathrm{cpm})$ of ${ }^{32} \mathrm{P}$-labelled probe, the mixture was incubated for an additional $30 \mathrm{~min}$ at room temperature.

For experiments in Fig. 4B, mutant oligonucleotides (mutated sequences are underlined) were synthesised and included in the reaction mixture as follows. For analysis of the footprint 1 region: 1-1, AAAAACCTCCGCGGGAGGGGGAGGGGACGGCGGGAAACG; 1-2, CGGGGAAAAAGCGGGAGGGGGAGGGGACGGCGGGAAACG; 1-3, CGGGGCCTCCAAAAAAGGGGGAGGGGACGGCGGGAAACG; 1-4, CGGGGCCTCCGCGGGAAAAAGAGGGGACGGCGGGAAACG; 1-5, CGGGGCCTCCGCGGGAGGGGAAAAAGACGGCGGGAAACG; 1-6, CGGGGCCTCCGCGGGAGGGGGAGGGAAAAACGGGAAACG; 1-7, CGGGGCCTCCGCGGGAGGGGGAGGGGACGGAAAAAAACG; and 1-8, CGGGGCCTCCGCGGGAGGGGGAGGGGACGGCGGGAAAAA.

For supershift experiments, the indicated antibodies (1 to $3 \mu \mathrm{g}$ ) were added to the reaction mixture before the incubation with labelled probe, and the resulting mixture was then incubated for an additional $30 \mathrm{~min}$ at room temperature. Polyclonal antibodies to Sp1, Sp2, Sp3, Sp4, GKLF, HSF-1, AP2 $\alpha$, or E2F-1 were obtained from Santa Cruz Biotechnology (Santa Cruz, Calif., USA). All reaction mixtures were finally fractionated by electrophoresis on a nondenaturing $5 \%$ polyacrylamide gel, which was then dried and subjected to autoradiography with Kodak Biomax MS film.

Ultraviolet $(U V)$-induced cross-linking. A 22-nucleotide double-stranded oligomer based on the sequence of the footprint 1 region and its mutated derivatives were prepared and labelled as described above for EMSA experiments. The sequences $\left(5^{\prime} \rightarrow 3^{\prime}\right)$ of these oligonucleotides were as follows (mutated sequences underlined): the wild-type probe, (-765)CCGCGGGAGGGGGAGGGGACGG(-744); dual-mutant probe, CCGCGGAAAGGGGAAAGGACGG; front-mutant probe, CCGCGGAAAGGGGAGGGGACGG; and rear-mutant, CCGCGGGAGGGGGAAAGGACGG. Labelled probes were incubated with $10 \mu \mathrm{g}$ of HepG2 nuclear extract in a volume of $50 \mu \mathrm{l}$ to allow binding to reach equilibrium, as described above for EMSA analysis. The reaction mixture was then cooled on ice and irradiated for 20 or $60 \mathrm{~min}$ at a distance of $5 \mathrm{~cm}$ with a UV transilluminator fitted with a $254 \mathrm{~nm}$ filter (Funakoshi, Tokyo, Japan). Samples were not treated with nuclease given that the substrate DNAs were labelled at their 5' ends. Cross-linked complexes were analysed by SDS-polyacrylamide gel electrophoresis (PAGE) on a 10\% gel as described [22] and visualised by autoradiography.

Southwestern blot analysis. HepG2 nuclear extract (15 and $60 \mu \mathrm{g}$ ) was subjected to SDS-PAGE on a $10 \%$ gel and the separated proteins were transferred electrophoretically to a polyvinylidene difluoride membrane (Millipore, Medford, Mass., USA). The membrane was incubated at room temperature for $30 \mathrm{~min}$ in hybridization buffer [10 mmol/l HEPES-KOH (pH 7.9), $50 \mathrm{mmol} / \mathrm{l} \mathrm{KCl}, 5 \mathrm{mmol} / \mathrm{MgCl}_{2}, 1 \mathrm{mmol} / \mathrm{l}$ EDTA, $0.5 \mathrm{mmol} / \mathrm{l} \mathrm{DTT}, 5 \%$ glycerol] containing $5 \%$ non-fat dried milk, and then rinsed twice with the same buffer containing $0.25 \%$ non-fat dried milk. The membrane was then exposed for $2 \mathrm{~h}$ at room temperature to an end-labelled double-stranded oligonucleotide corresponding to either the wild-type or dual-mutant probe (described above for UV cross-linking) in hybridisation buffer containing $0.25 \%$ non-fat dried milk. After washing four times with hybridization buffer containing $0.25 \%$ non-fat dried milk, the membrane was dried and subjected to autoradiography.

Patients and control subjects. All study subjects $(n=549)$ were Japanese, unrelated and gave their written informed consent to participate in the study for the identification of Type II diabetes genes in Japan $[23,24]$. They were 301 patients with Type II diabetes [176 men, 125 women; age, 63.7 \pm 10.1 years (mean \pm SD); BMI, $23.1 \pm 3.3 \mathrm{~kg} / \mathrm{m}^{2}$ ] and 248 healthy control subjects (114 men, 134 women; age, 75.7 \pm 8.5 years; BMI, $\left.21.4 \pm 3.7 \mathrm{~kg} / \mathrm{m}^{2}\right)$. The diagnosis of diabetes mellitus was based on the criteria of the World Health Organization [25]. The healthy control subjects were selected according to the following criteria: no past history of urinary sugar or of glucose intolerance, an $\mathrm{HbA}_{1 \mathrm{c}}$ level of less than $5.6 \%$, an age of older than 60 years, and no family history of diabetes mellitus. These criteria which could enhance statistical power to detect associations were also used in previous reports from our laboratory $[23,24]$. The investigation was carried out in accordance with the guidelines expressed in the Declaration of Helsinki.

Clinical assessment. The sex and present age were ascertained from medical records. Present BMI were directly measured when we collected blood samples to obtain DNA. The fasting plasma concentration of glucose (FPG), the fasting plasma concentration of immunoreactive insulin (f-IRI), and the $\mathrm{HbA}_{1 \mathrm{c}}$ level were measured by standard laboratory techniques. Based on the assumption that control subjects younger than 35 years and of normal weight exhibit $100 \%$ beta-cell function and an insulin resistance of 1 , the corresponding values for those with diabetes can be assessed from FPG and f-IRI by the following formulas: homeostasis model assessment for beta-cell function (HOMA- $\beta$, expressed as a percentage) $=$ f-IRI $\times 20 /($ FPG-3.5), and homeostasis model assessment for insulin resistance (HOMA-R, expressed in mol $\mu \mathrm{U} \mathrm{l}^{-2}$ ) = FPG $\times f-I R I / 22.5$ [26].

Screening and genotype analysis of the single nucleotide polymorphisms (SNPS). Genomic DNA was isolated from the peripheral blood leukocytes of all study participants and subjected to PCR-based direct sequence to screen 25 diabetic patients for mutations in the $5^{\prime}$ flanking region of human IRS2. PCR-based direct sequence was also carried out to assess the genotypes with regard to the detected $-765 C / T$ polymorphism. Fragments of IRS 2 encompassing the polymorphic site $(-765 C / T)$ were amplified by PCR with the sense primer 5'-CCACAACAAGCCGCTGATTAT-3' and the antisense primer 5'-TTGCTGCTGCTGCTGCCAAC- $3^{\prime}$, and subjected to direct sequencing analysis. For $-2062 T / C$ polymorphism, PCR and restriction fragment length polymorphism analysis (PCR-RFLP) was done to evaluate its allele frequencies. Fragments of the human IRS2 encompassing the polymorphic site $(-2062 T / C)$ were amplified by PCR with the sense primer $5^{\prime}$-CTAACTGTATACATGCTAAAAAT- $3^{\prime}$ and the antisense primer 5'-AACAAAACAGGCTTT- $3^{\prime}$. The resulting PCR product obtained from subjects with the T allele contains a Ssp I restriction site but not with the $\mathrm{C}$ allele. The 334- bp PCR products of IRS2 were therefore digested with Ssp I, subjected to electrophoresis on a $12 \%$ polyacrylamide gel, and visualised by staining with ethidium bromide. The genotype of each study subject was determined blindly, without knowledge of clinical status.

Statistical analysis. All data are presented as means \pm SD or proportions. The allele frequencies for SNPs between Type II diabetic and control groups were compared by a standard chi-square test. Other categorical variables were also compared by the chi-square test. An estimation of linkage disequilibrium 
between the detected two SNPs was done by using the Estimating Haplotype $(\mathrm{EH})$ frequencies version 1.11 software program (ftp://linkage.rockefeller.edu/software/eh). Comparison of quantitative variables was done using ANOVA. The effect of genotype on the clinical parameters was estimated by analysis of covariance (ANCOVA) using genotype as a factor and age and sex as covariates. Statistical analyses except the estimation of linkage disequilibrium was done with Stat View Version 5.0 (SAS Institute, Cary, N.C., USA). A $p$ value of less than 0.01 was considered to be significant in the context of multiple testing.

\section{Results}

Cloning and sequencing of the 5' flanking region of the human IRS2 gene. We isolated three human IRS2 clones by screening a genomic DNA library with two specific probes (Fig. 1A). All three clones reacted with both probes in Southern blot analysis and were subjected to partial sequencing, the results of which suggested that they contain most of the protein-coding region of IRS2. The results of Southern blot analysis, nucleotide sequencing, and restriction enzyme analysis showed that partial nucleotide sequences of clone 1 and clone 3 were consistent with each other and clone 1 contained the longest $5^{\prime}$ flanking sequence $(\sim 2.4 \mathrm{~kb})$ of the three clones. We thus selected clone 1 for further analysis.

The nucleotide sequence of clone 1 (nt -2399 to +217 , relative to the translation start site) is shown in Fig. 1B. A TATA box is located at nt -2190 to -2184 . Analysis of transcription factor binding sites with TFSEARCH located several putative binding motifs for various transcription factors in the $5^{\prime}$ flanking region of human IRS2 (Fig. 1A).

Activity of the IRS2 promoter in various cell types. To identify the portions of the $5^{\prime}$ flanking region of IRS2 required for maximal promoter activity, a series of 5 ' deletion mutants, constructed into the promoterless luciferase expression plasmid pGL3-Basic, were introduced into HepG2, Fao, RINm5F, and HeLa cells. We used these cell lines because IRS2 is abundantly expressed in liver and was suggested to be involved in the beta-cell proliferation. The promoter activity of

Fig. 1A,B. Structural organisation and nucleotide sequence of the promoter region of human IRS2. A Structural organisation of the $5^{\prime}$ flanking region of human IRS2. The small filled boxes above the representation of the gene correspond to the probes used to screen the human genomic DNA library. The positions of the three genomic DNA fragments (clones 1, 2, and 3) isolated from this library are also indicated. The locations of a TATA box, the predicted transcription initiation site, the translation initiation codon (ATG), and putative transcription factor binding sites are shown in the lower schematic. B Nucleotide sequence of the promoter region of human IRS2. The $5^{\prime}$ flanking sequence is shown in uppercase letters and the coding sequence in lowercase letters. The underlined sequence indicates the TATA element. All positions are numbered relative to the A of the translation start codon (ATG) as position +1 . (The human IRS2 promoter sequence has been deposited in DDBJ/ EMBL/GenBank under the accession number AB050954) each deletion mutant was then evaluated by assay of luciferase activity in extracts of the transfected cells.

Deletion analysis in HepG2 cells showed that truncation of the $5^{\prime}$ upstream sequence from nt -2399 [pGL3-IRS2(-2399)] to $\mathrm{nt}-834$ [pGL3-IRS2(-834)] had no marked effect on the transcriptional activity of the human IRS2 promoter. Further deletion to position

A

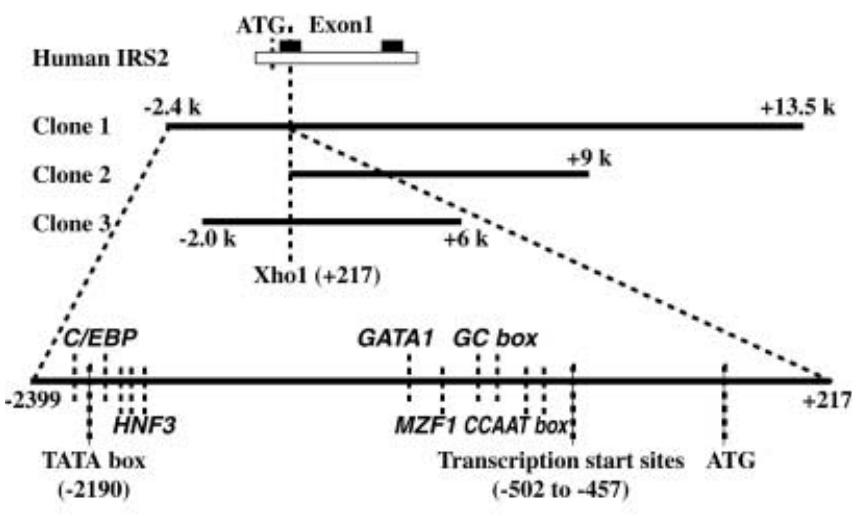

B

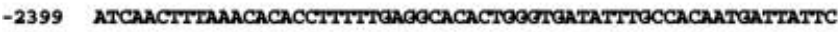
TTССCANATCAOOCTACTCATCAATAATCCTAACTGTATACATOCTAAAAATAANACO

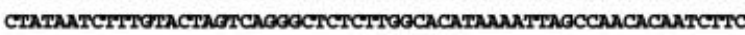

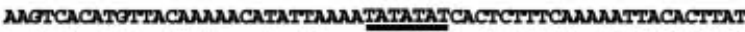
TITCTCTTACATTAACATTTTATTACTTTTAACATACTTCTATCAATTATACACCACATC CAAAAOTAAACATCCGGCACTTAAAAACAATAACCAATATTATAACATAAATTATTOCTO TAAATTATTTCATEAAOGCACAATTAAAAAAAAAATAAAATAAACAOCCAAAOCCTOTTT

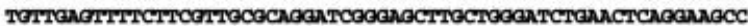

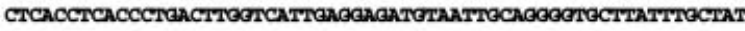

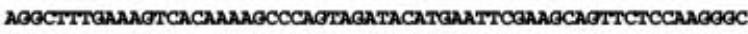

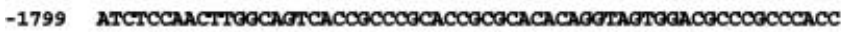

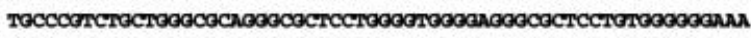

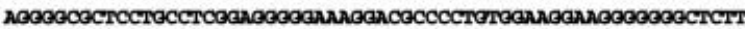

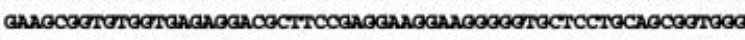

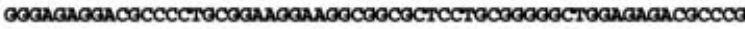

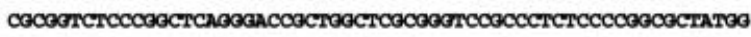

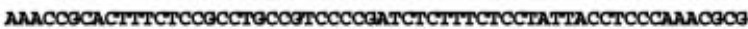

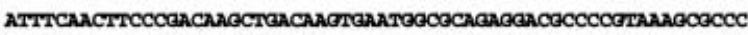

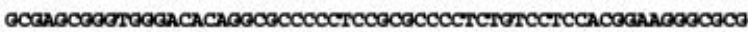

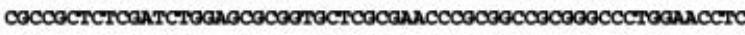

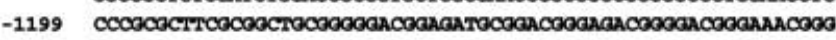

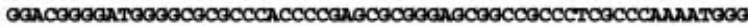
aACCCCGCOCCCCGA

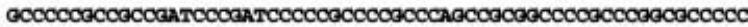

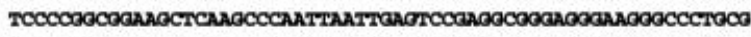
COCCORT

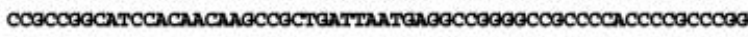

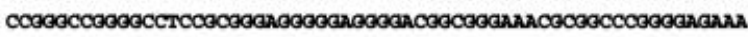

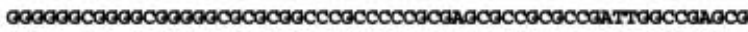

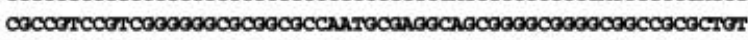

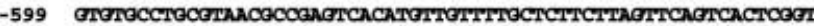

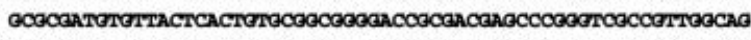

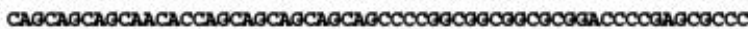

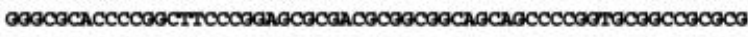

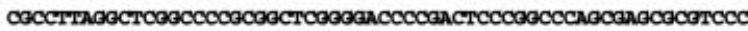

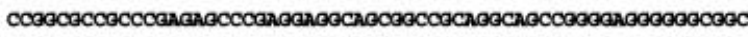

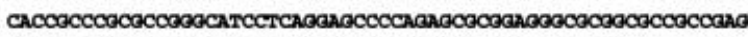

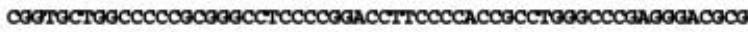

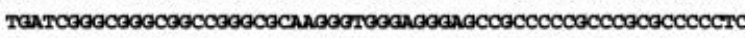

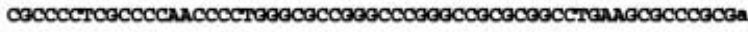

+2 tggogagooogoogoggoaogggoogooogggooggogagoggagaoggoccoanactca acaacaacancancaacancanccacagogtgogcangtgoggctacctgogcangcaga agcatggecacaagogettcttogtgotgogoggaccoggogogggoggogaogaggoga oggogggoggggggtoggogoogoanoogoogoggo 

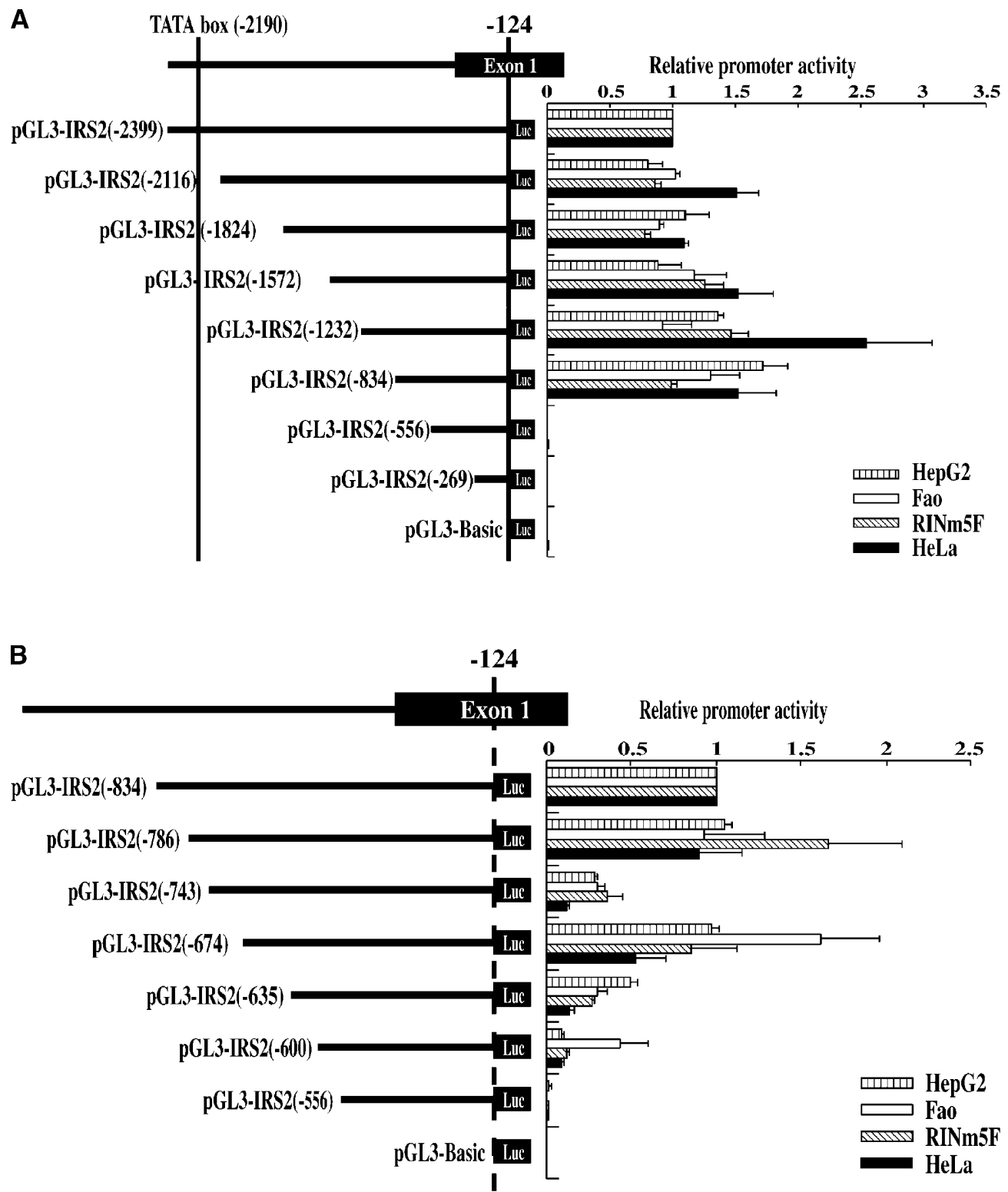

Fig. 2A,B. Effects of deletion of the human IRS2 promoter on transcriptional activity. The 2.4-kb 5' flanking region of IRS2 and its deletion mutants are shown in the left panels. The promoter fragments, terminating at $n t-124$ and beginning at the indicated positions between -2399 and -269 , were inserted into pGL3-Basic, and the resulting constructs were introduced into HepG2, Fao, RINm5F or HeLa cells. Normalised firefly luciferase activity of cell lysates is shown in the right panels and is expressed as a percentage of that apparent in cells transfected either with pGL3-IRS2(-2399) (A) or with pGL3IRS2(-834) (B). Data are means \pm SE of values from three to six experiments and two independent transfections

-556 , however, reduced the promoter activity to about $0.5 \%$ of that apparent with pGL3-IRS2(-2399) (Fig. 2A). Similar results were observed when these deletion constructs were transfected in other three cell lines (Fig. 2A). These data indicated that the core promoter of human IRS 2 is located within the $278-\mathrm{bp}$ region between $n t-834$ and -557 .
To delineate more precisely the transcriptional regulatory elements within the core promoter of IRS2 spanning nt -834 to -556 , we prepared an additional series of deletion mutants and measured their transcriptional activities in four different cell lines (Fig. 2B). Compared with the activity of the pGL3IRS2(-834) construct, deletion to position -786 [pGL3-IRS2(-786)] did not affect promoter activity whereas deletion to position -743 [pGL3-IRS2(-743)] resulted in approximately a $70 \%$ decrease in activity. Further deletion to position -674 restored the promoter activity to between 50 and $100 \%$ of that of pGL3IRS2(-834), whereas progressive deletions from nt -674 to $n t-556$ resulted again in a gradual decrease in activity. These results indicated that sequences located between positions -786 and -744 and between positions -674 and -557 positively regulate IRS2 promoter activity, whereas a sequence between positions -743 and -675 negatively regulates the promoter activity. 


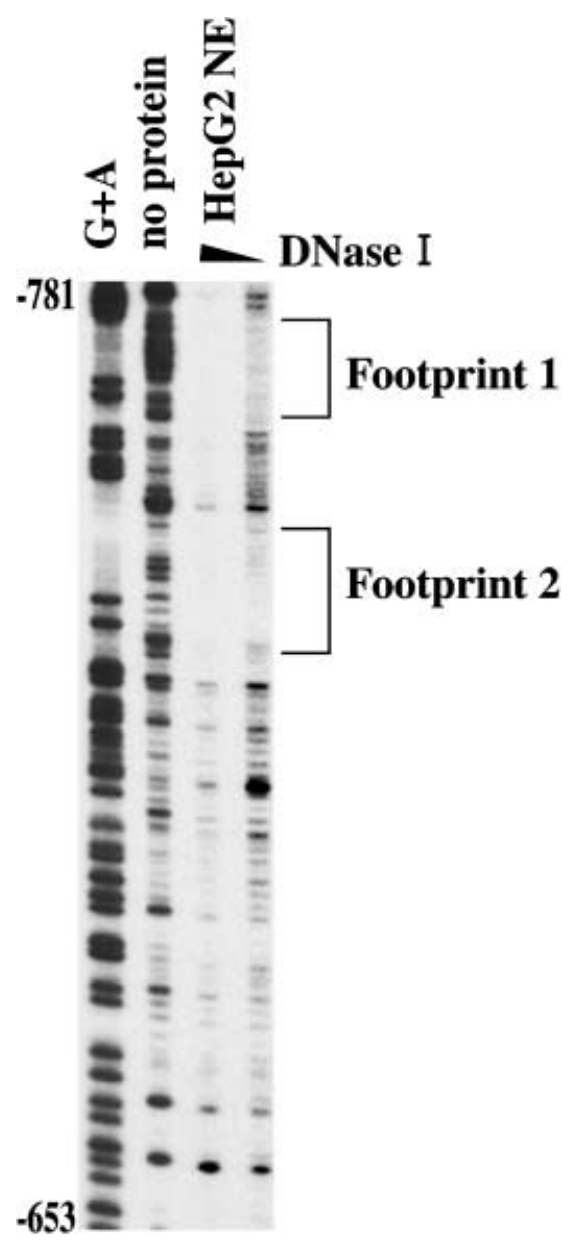

Fig. 3. DNase I footprint analysis of the IRS2 core promoter region. A double-stranded DNA probe corresponding to nt -904 to -611 of human IRS2 and end-labelled with ${ }^{32} \mathrm{P}$ was incubated in the absence or presence of $30 \mu \mathrm{g}$ of HepG2 nuclear extract (NE) and subsequently digested with decreasing amount of DNase I. Sequence analysis of the antisense DNA strand is shown, with numbers corresponding to nucleotide positions. Two regions protected from DNase I digestion by the nuclear extract are designated footprints 1 and 2 . Lane $\mathrm{G}+\mathrm{A}, \mathrm{G}+\mathrm{A}$ sequencing ladder of the probe. Data are representative of six similar experiments

DNase I footprint analysis of the IRS2 gene promoter. To locate the sequence of IRS2 in which regulatory proteins potentially bind to the core promoter region of IRS 2 identified by deletion analysis, we did a DNase I footprint analysis with a crude nuclear extract of human hepatoma HepG2 cells and a DNA probe corresponding to nt -904 to -611 of IRS2. Two footprints of 39 and $25 \mathrm{bp}$ were identified: footprint 1 , nt -773 to -735 , and footprint 2 , nt -726 to -702 , respectively (Fig. 3). Similar results were obtained when we used a different DNA probe corresponding to $\mathrm{nt}-878$ to -512 of IRS2.

Analysis of the DNA sequences of footprint 1 and footprint 2 showed the presence of binding motifs in both footprints for various transcription factors, including those for ADR1 and heat shock factor (HSF) as well as GC boxes. In addition, activator protein 2
(AP2), E2 promoter binding factor (E2F), and MZF1 binding sites were detected in footprint 1 .

EMSA analysis. To corroborate the results of the DNase I footprint analysis and to identify DNA-binding proteins that interact with the IRS 2 promoter, we prepared a synthetic oligonucleotide encompassing footprint 1 (nt -773 to -735 ) and subjected it to EMSA analysis with HepG2 nuclear extract.

Incubation of the ${ }^{32} \mathrm{P}$-labelled probe with $\mathrm{HepG} 2$ nuclear extract resulted in the appearance of three major shifted bands (Fig. 4A, arrows) that were not detected in the presence of excess unlabelled probe. Unlabelled oligonucleotides that contained a GC box or the consensus binding sites for AP2, E2F, HSF, ADR1, or MZF1 did not compete with the ${ }^{32} \mathrm{P}-1 \mathrm{a}-$ belled probe in its interactions with extract proteins. Supershift analysis showed that polyclonal antibodies to $\mathrm{Sp} 2$ or to $\mathrm{Sp} 3$ reduced the mobility of the proteinDNA complexes formed by the footprint 1 probe (Fig. 4A, arrowheads).

To identify the nucleotide sequence(s) within footprint1 region that are responsible for the formation of observed DNA-protein complexes, we examined the effects of eight mutant oligonucleotides (footprint 1-1 to 1-8) containing sequential disruptions in the footprint 1 sequence on the formation of DNA-protein complexes by the ${ }^{32} \mathrm{P}$-labelled footprint 1 probe. Whereas excess footprint 1-4 and footprint 1-5 oligonucleotides had virtually no effect on the DNA-protein complexes formed by the footprint 1 probe, each of the other six mutant oligonucleotides efficiently competed with the footprint 1 probe in the formation of these complexes (Fig. 4B). These results, together with the findings obtained by luciferase assays (Fig. 2), indicated that the sequences mutated in the footprint 1-4 and 1-5 oligonucleotides (nt -758 to -749) positively regulate the transcriptional activity of the IRS 2 promoter by binding unknown nuclear proteins. It was also showed that the consensus binding motifs for either Sp2 or Sp3 were not identical with the identified cis regulatory element (nt -758 to $-749)$.

We also examined by EMSA analysis to identify DNA-binding proteins that interact with the footprint 2 (nt -726 to -702). Incubation of the ${ }^{32} \mathrm{P}-$ labelled probe corresponding to footprint 2 with HepG2 nuclear extract resulted in the appearance of one major and two minor shifted bands that were not detected in the presence of excess unlabelled probe (lane 2 in Fig. 4C). An excess of unlabelled oligonucleotides containing a consensus GC box slightly reduced the intensity of the two minor bands. Consistent with this effect, given that $\mathrm{Sp}$ proteins interact with the GC box, supershift analysis showed that polyclonal antibodies to Sp2 or to SP3 reduced the mobility of the two minor DNA-protein complexes formed by the footprint2 probe (Fig. 4C). Specifically, the antibodies 
A

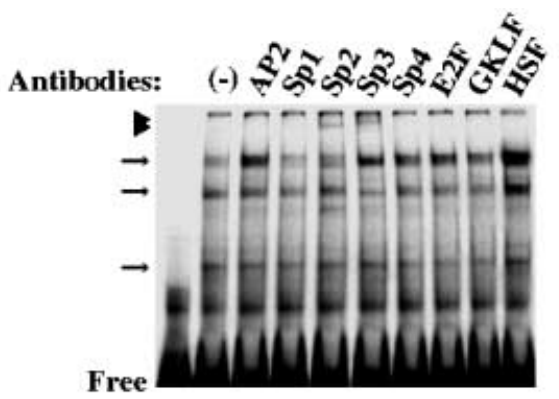

B

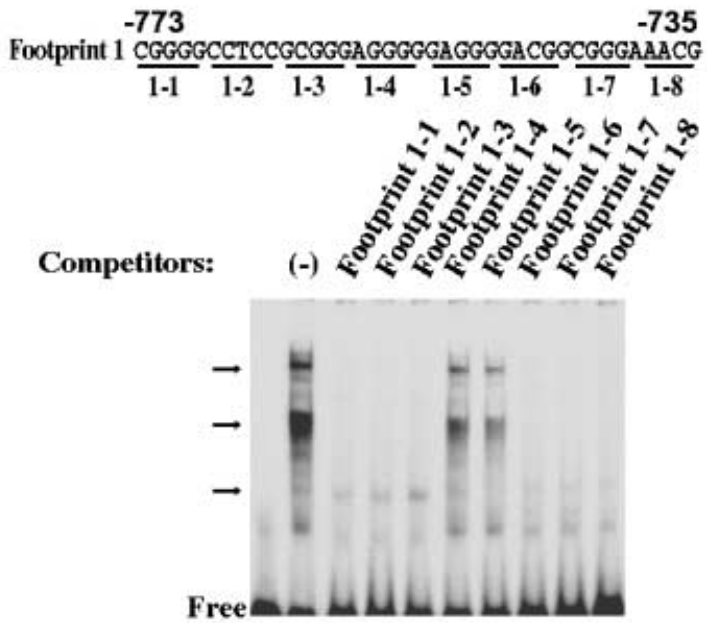

C

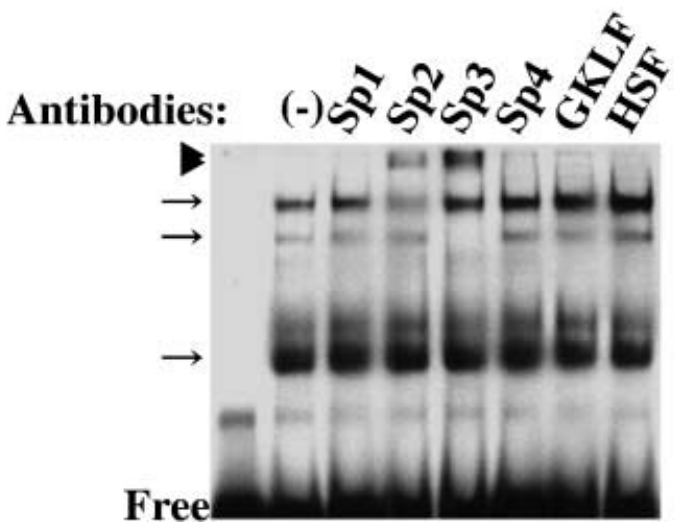

Fig. 4A-C. EMSA analysis with an oligonucleotide corresponding to footprints of the human IRS2 promoter. EMSA analysis was done with HepG2 nuclear extract $(5 \mu \mathrm{g})$ and a 32P-labelled double-stranded oligonucleotide encompassing (A, B) footprint 1 (nt -773 to -735 ) and (C) footprint 2 (nt -726 to -702) of the IRS2 promoter. (A, C) Supershift analysis was done in the presence of antibodies to the indicated proteins. (B) Competition analysis was performed in the presence of each of eight oligonucleotides (footprint 1-1 to 1-8) corresponding to the footprint 1 sequence in which the underlined nucleotides were replaced by an equivalent number of A residues. In lane 1 of all panels, the ${ }^{32} \mathrm{P}$-labelled footprint 1 probe was applied to the gel without prior incubation with nuclear extract. Shifted bands are indicated with arrows and supershifted bands with arrowheads. Free, free probe. Data are representative of three similar experiments

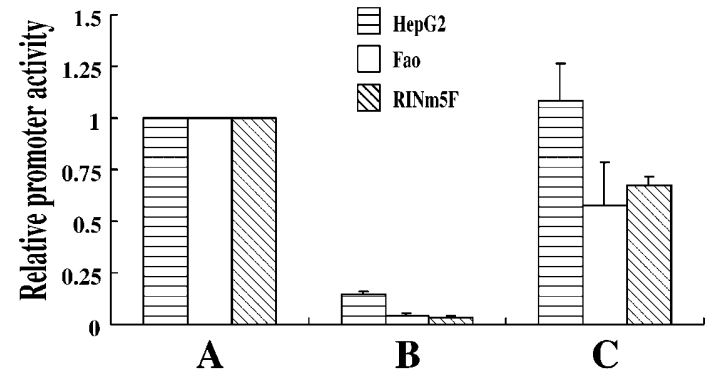

Fig. 5. Effects of point mutations of the human $I R S 2$ promoter on transcriptional activity. Promoter activity of pGL3-IRS2 (-834) (panel A) and mutations introduced to disrupt potential protein binding sequences in footprints 1 (panel B) and 2 (panel C). The normalised firefly luciferase activity of HepG2, Fao and RINm5F cells transfected with each construct was measured and expressed relative to that of pGL3-IRS2(-834). Data are means \pm SE of values from three to six experiments and two independent transfections

to SP3 induced total displacement of one of the shifted bands whereas the antibodies to Sp2 slightly affected both bands. None of the tested antibodies affected the mobility of the major DNA-protein complex formed by the footprint 2 probe. These results suggested that proteins that interact with the GC box play a minor part in the regulation of IRS2 in this region of the promoter.

Effect of mutation of footprint regions on IRS2 promoter activity. We introduced mutations into pGL3IRS2(-834) to disrupt the cis regulatory element in footprint 1 (nt -758 to -749 ) as identified in the above experiment as well as footprint 2 region. The promoter activity of the resulting constructs was assessed in HepG2, Fao, and RINm5F cells. Disruption of the nucleotide sequence in the cis regulatory element in the footprint 1 region resulted in a significant reduction in promoter activity to about $14 \%$ in HepG2, $4 \%$ in Fao, and $3 \%$ in RINm5F cells, respectively, of those apparent with pGL3-IRS2(-834) (Fig. 5A,B). Disruption of GC boxes between positions -715 and -703 of the footprint 2 sequences did not affect promoter activity compared with that of pGL3-IRS2(-834) (Fig. 5C). These results thus largely confirmed the data obtained by EMSA analysis and emphasised the contribution of the cis regulatory element, nt -758 to -749 , of footprint 1 in the positive regulation of IRS2 promoter activity whereas the footprint 2 sequence seemed less important.

UV cross-linking and Southwestern blot analysis of the footprint 1 sequence. To gain further insight into the nature of the proteins that interact with the identified cis regulatory element (nt -758 to -749 ) in footprint 1 , we next carried out UV cross-linking experiments in which the mixtures containing HepG2 nuclear extract and ${ }^{32} \mathrm{P}-$ Labelled synthetic oligonucleotides encoding the wild-type or mutant cis regulatory ele- 


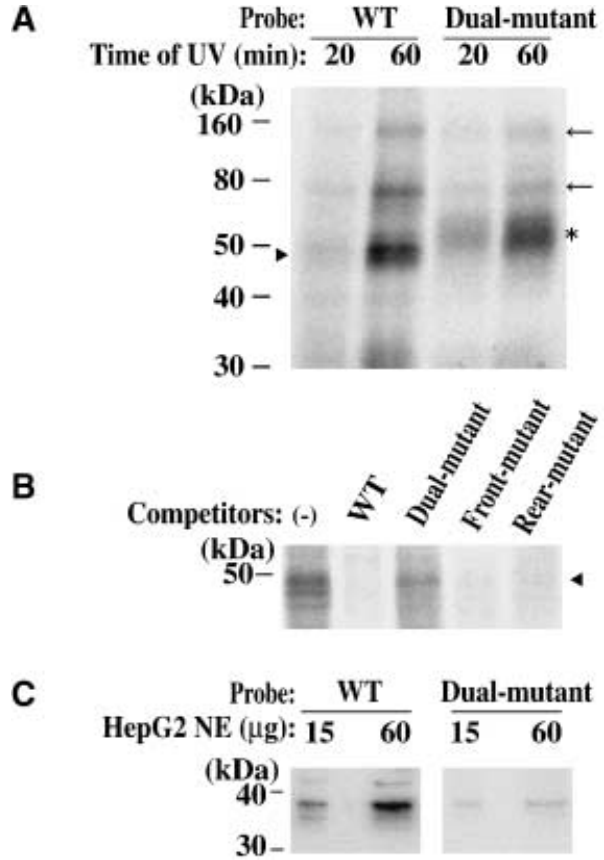

Fig. 6A-C. Characterisation of the protein that interacts with the cis-element of footprint 1 region in the human IRS 2 promoter. A UV cross-linking analysis. The cross-linked complexes obtained by incubating either the wild-type (WT) or dualmutant ${ }^{32} \mathrm{P}$-Labelled double-stranded oligonucleotides with HepG2 nuclear extract were exposed to UV light for 20 or $60 \mathrm{~min}$ and were analysed. The arrowhead and arrows indicate the major $\left(\sim 50000 \mathrm{M}_{\mathrm{r}}\right)$ and minor complexes formed, respectively. The asterisk indicate the major complex formed only by dual-mutant probe. B Competition analysis of UV crosslinking. The ${ }^{32} \mathrm{P}$-labelled wild-type probe was incubated with nuclear extract in the presence of a 200-fold molar excess of unlabelled wild-type, dual-mutant, front-mutant, or rearmutant oligonucleotides, after which the reaction mixtures were exposed to UV radiation for $60 \mathrm{~min}$. C Southwestern blot analysis. HepG2 nuclear extract ( 15 or $60 \mu \mathrm{g}$ ) was resolved by SDS-PAGE, and the separated proteins were transferred to a polyvinylidene difluoride membrane and probed with ${ }^{32} \mathrm{P}-\mathrm{la}-$ belled double-stranded oligonucleotides containing the wildtype (WT) or Dual-mutant probe. DNA-protein complexes were detected by autoradiography. The positions of molecular size markers are indicated in kilodaltons. Data are representative of three similar experiments

ment were analysed. The mixtures were then subjected to UV irradiation for 20 or $60 \mathrm{~min}$, and crosslinked DNA-protein complexes were analysed by SDS-PAGE and autoradiography. A major band migrating at a position corresponding to a molecular size of about $50000 \mathrm{M}_{\mathrm{r}}$ (lane 2, arrowhead in Fig. 6A) and two minor bands at about 75000 and $150000 \mathrm{M}_{\mathrm{r}}$ (lane 2, arrows in Fig. 6A) were detected with the wild-type probe. In contrast, the mutant oligonucleotide gave rise to a major band of about $60000 \mathrm{M}_{\mathrm{r}}$ (lane 4, asterisk in Fig. 6A) and two minor bands at about 75000 and $150000 \mathrm{M}_{\mathrm{r}}$ (Fig. 6A, lane 4). These results indicated that the $50000 \mathrm{M}_{\mathrm{r}}$ complex could contain the protein that binds to the sequence containing the cis-element to increase the transcriptional
Table 1. Genotypes and allele frequencies for the $-765 C / T$ and the $-2062 T / C$ polymorphisms in 5' UTR of IRS2 for study subjects

\begin{tabular}{lcc}
\hline & $\begin{array}{l}\text { Type II diabetes } \\
(n=301)\end{array}$ & $\begin{array}{l}\text { Control subjects } \\
(n=248)\end{array}$ \\
\hline Genotype $-765 C / T$ & & \\
$C C$ & 57 & 59 \\
$C T$ & 161 & 110 \\
$T T$ & 83 & 79 \\
$T$ allele frequency (\%) & $54.3^{\mathrm{a}}$ & 54.0 \\
Genotype $-2062 T / C$ & & \\
$T T$ & 195 & 164 \\
$C T$ & 99 & 74 \\
$C C$ & 7 & 10 \\
$C$ allele frequency $(\%)$ & $18.8^{\mathrm{b}}$ & 18.9 \\
\hline
\end{tabular}

a $p=0.924$

${ }^{\mathrm{b}} p=0.939$ vs normal control group (chi-square test)

Data are presented in $n$ or in $\%$

activity of the IRS2 promoter. Competition analysis showed that, whereas oligonucleotides in which nt -759 to -757 or $n t-752$ to -750 were mutated effectively competed with the ${ }^{32} \mathrm{P}-$-labelled wild-type probe in the formation of the $50000-\mathrm{M}_{\mathrm{r}}$ complex, a mutant oligonucleotide in which both sequences were disrupted and did not compete (Fig. 6B). These data suggested that both of these sequences are required for the specific binding of the protein contained in the $\sim 50000 \mathrm{M}_{\mathrm{r}}$ complex. We did a Southwestern blot analysis with HepG2 nuclear extract to evaluate more precisely the molecular size of the protein contained in the $\sim 50000-\mathrm{M}_{\mathrm{r}}$ complex identified by UV crosslinking, given that this complex also contained the DNA probe. Blot analysis indicated that the size of the major protein that interacts with this sequence is about $37000 \mathrm{M}_{\mathrm{r}}$ (Fig. 6C), the intensity of which was decreased by the incubation with the dual-mutant probe.

Analysis for genetic variations in the $5^{\prime}$ UTR of the human IRS2. To investigate whether genetic variations contributing to the pathogenesis of Type II diabetes exist within the $5^{\prime}$ UTR of IRS2, this region was screened by PCR-based direct sequencing in 25 patients with Type II diabetes. We detected two SNPs: one substituting cytosine $(\mathrm{C})$ to thymine $(\mathrm{T})$ at position $-765(-765 C / T)$ and the other replacing $\mathrm{T}$ to $\mathrm{C}$ at position $-2062(-2062 T / C)$. Allele frequencies of the detected two SNPs were evaluated by PCR-based direct sequencing and PCR-RFLP analyses in 301 diabetic patients and 248 control subjects, respectively. The genotypes of both SNPs were in Hardy-Weinberg equilibrium and these two SNPs were in linkage disequilibrium $\left(\mathrm{D}=-0.072, \Delta^{2}=0.135, p=4.27 \times 10^{-19}\right)$. The allele frequencies for these two SNPs showed no difference between the Type II diabetic group and the control group (Table 1). 
Table 2. Characteristics of the study subjects

\begin{tabular}{|c|c|c|}
\hline & Type II diabetes & Control subjects \\
\hline$n$ (men/women) & $301(176 / 125)$ & $248(114 / 134)$ \\
\hline Age (years) & $63.7 \pm 10.1(n=301)$ & $75.7 \pm 8.5(n=248)$ \\
\hline Height $(\mathrm{cm})$ & $160 \pm 8.9(n=298)$ & $155 \pm 9.0(n=245)$ \\
\hline Weight (kg) & $59.0 \pm 10.7(n=298)$ & $51.1 \pm 10.2(n=246)$ \\
\hline $\mathrm{BMI}\left(\mathrm{kg} / \mathrm{m}^{2}\right)$ & $23.1 \pm 3.3(n=297)$ & $21.4 \pm 3.7(n=245)$ \\
\hline Maximum BMI $\left(\mathrm{kg} / \mathrm{m}^{2}\right)$ & $26.6 \pm 3.6(n=285)$ & \\
\hline Waist-to-hip ratio & $0.90 \pm 0.08(n=255)$ & \\
\hline $\mathrm{HbA}_{1 \mathrm{c}}(\%)$ & $7.41 \pm 1.40(n=300)$ & $5.05 \pm 0.38(n=248)$ \\
\hline FPG (mg/dl) & $139 \pm 52(n=270)$ & $94 \pm 15(n=185)$ \\
\hline Fasting IRI $(\mu \mathrm{U} / \mathrm{ml})$ & $9.23 \pm 10.5(n=143)$ & \\
\hline HOMA-R (mol $\left.\mu \mathrm{U} \mathrm{l}^{-2}\right)$ & $2.97 \pm 2.88(n=140)$ & \\
\hline
\end{tabular}

Data are presented in means $\pm \mathrm{SD}(n)$

FPG, Fasting plasma glucose; IRI, immunoreactive insulin;

HOMA-R, homeostasis model assessment for insulin resis- tance; HOMA- $\beta$, homeostasis model assessment for beta-cell function

Table 3. Comparison of clinical profiles for the $-765 C / T$ polymorphisms in $5^{\prime}$ UTR of $I R S 2$ for diabetic patients

\begin{tabular}{|c|c|c|c|c|}
\hline & $C C$ & $C T$ & $T T$ & $p$ value \\
\hline$n$ (men/women) & $57(32 / 25)$ & $161(95 / 66)$ & $83(49 / 34)$ & \\
\hline Age (years) & $64.3 \pm 11.8(n=57)$ & $62.5 \pm 9.6(n=161)$ & $65.4 \pm 9.8(n=83)$ & 0.094 \\
\hline Height $(\mathrm{cm})$ & $160 \pm 9.5(n=57)$ & $160 \pm 8.9(n=159)$ & $159 \pm 8.6(n=82)$ & 0.862 \\
\hline Weight (kg) & $58.5 \pm 10.0(n=56)$ & $58.8 \pm 11.1(n=159)$ & $59.8 \pm 10.5(n=83)$ & 0.712 \\
\hline $\mathrm{BMI}\left(\mathrm{kg} / \mathrm{m}^{2}\right)$ & $23.0 \pm 3.1(n=56)$ & $22.9 \pm 3.4(\mathrm{n}=159)$ & $23.4 \pm 3.5(n=82)$ & 0.539 \\
\hline Maximum BMI $\left(\mathrm{kg} / \mathrm{m}^{2}\right)$ & $26.9 \pm 3.5(n=55)$ & $26.3 \pm 3.5(n=151)$ & $26.9 \pm 4.1(n=79)$ & 0.467 \\
\hline Waist-to-hip ratio & $0.90 \pm 0.08(n=50)$ & $0.90 \pm 0.08(n=136)$ & $0.90 \pm 0.08(n=69)$ & 0.884 \\
\hline $\mathrm{HbA}_{1 \mathrm{c}}(\%)$ & $7.46 \pm 1.30(\mathrm{n}=57)$ & $7.43 \pm 1.47(n=160)$ & $7.36 \pm 1.37(n=83)$ & 0.900 \\
\hline FPG (mg/dl) & $133 \pm 49(n=49)$ & $138 \pm 47(n=148)$ & $143 \pm 63(n=73)$ & 0.541 \\
\hline Fasting IRI $(\mu \mathrm{U} / \mathrm{ml})$ & $11.3 \pm 19.4(n=29)$ & $8.61 \pm 6.46(n=76)$ & $8.88 \pm 6.86(n=38)$ & 0.486 \\
\hline HOMA-R (mol $\left.\mu \mathrm{U} \mathrm{l}^{-2}\right)$ & $2.78 \pm 2.92(n=27)$ & $2.93 \pm 2.64(n=76)$ & $3.18 \pm 3.37(n=37)$ & 0.845 \\
\hline
\end{tabular}

a $p$ values were obtained by one-way ANOVA

Data are presented in means \pm SD $(n)$

FPG, Fasting plasma glucose; IRI, immunoreactive insulin;

HOMA-R, Homeostasis model assessment for insulin resis- tance; HOMA- $\beta$, Homeostasis model assessment for beta-cell function
The clinical characteristics of the Type II diabetic and control subjects are summarised (Table 2). Among the Type II diabetic patients, no association of genotype for the $\operatorname{SNP}(-765 C / T)$ with clinical profiles (age, sex, BMI, $\mathrm{HbA}_{1 \mathrm{c}}$, and fasting plasma glucose) were apparent (Table 3 ). Significant association of genotype for the $\operatorname{SNP}(-765 C / T)$ with clinical profiles were neither apparent among the control subjects (Table 4) except that the $\mathrm{HbA}_{1 \mathrm{c}}$ level was lower in subjects bearing $\mathrm{T}$ allele(s) at $\mathrm{nt}-765(-765 C / T$ or $-765 T / T)$ when analysed statistically by ANOVA $\left({ }^{\mathrm{a}} p=0.003\right.$, Table 4$)$ and by ANCOVA using genotype as a factor and age and sex as covariates $(\mathrm{b} p=0.006$, Table 4). When we compared the clinical profiles in healthy subjects between the $\operatorname{SNP}(-765 C / C)$ carriers and subjects bearing $\mathrm{T}$ allele(s) at $\mathrm{nt}-765$ [SNP(-765C/T) carriers plus $\operatorname{SNP}(-765 T / T)$ carriers] by two-tailed Student's $t$ test, the $\mathrm{HbA}_{1 \mathrm{c}}$ level and fasting plasma glucose concentration were lower in the latter $\left[\mathrm{HbA}_{1 \mathrm{c}}, 5.17 \pm 0.31 \quad(n=59)\right.$ vs $5.01 \pm 0.39$ $(n=189),{ }^{\mathrm{a}} p=0.008$; FPG, $99 \pm 19 \quad(n=45)$ vs $92 \pm 14$ $(n=140), p=0.011]$. Although a gene dosage effect was not evident by having $C$ allele at nt -765 , these results suggested an adverse role of the minor allele homozygous (CC) in sustaining the lower $\mathrm{HbA}_{1 \mathrm{c}}$ level. Associations of genotype for the $\operatorname{SNP}(-2062 T / C)$ with clinical profiles were neither significant among the diabetic and control subjects. These results suggested 

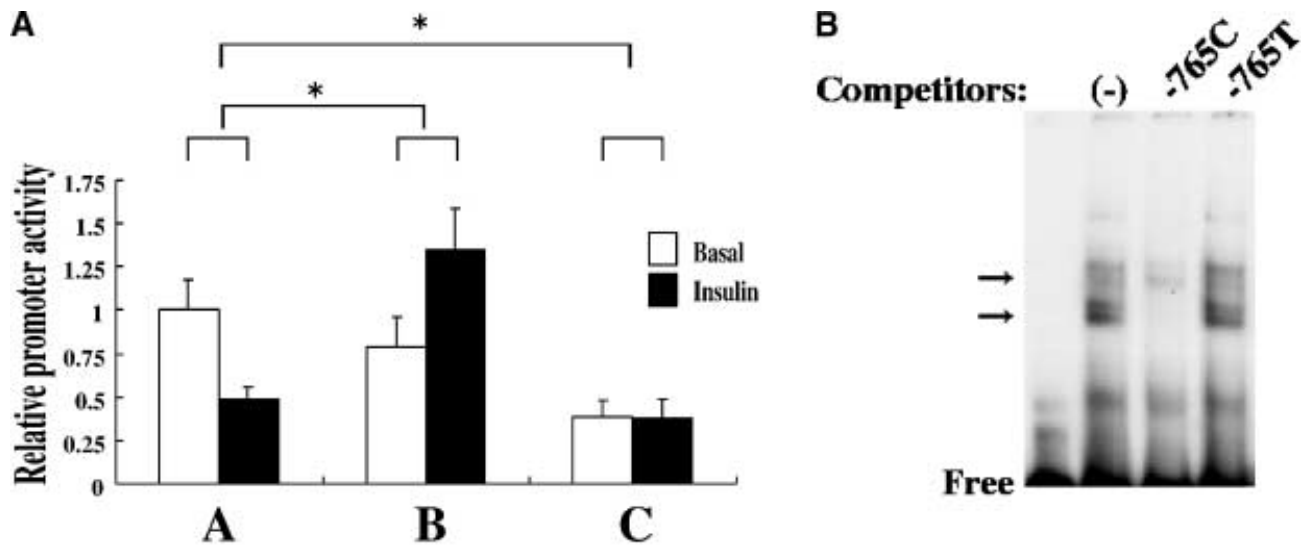

Fig. 7A, B. A Effect of $\mathrm{SNP}(-765)$ and insulin responsive element (IRE) on the promoter activity. Point mutations were introduced into pGL3-IRS2 $(-834)$ to substitute $\mathrm{C}$ at nucleotide position to -765 with $\mathrm{T}$ [pGL3-IRS2(-765T)] or to disrupt sequence in the insulin-responsive element (IRE) [pGL3-IRS2mutIRE]. The normalised firefly luciferase activity of Fao cells transfected with pGL3-IRS2(-834) (panel A), pGL3-IRS2 (-765T) (panel B), or pGL3-IRS2-mutIRE (panel C) in the absence or presence of $100 \mathrm{nmol} / \mathrm{l}$ insulin was measured and expressed relative to that of pGL3-IRS2(-834) in the absence of insulin. Data are means $\pm \mathrm{SE}$ of values from six independent

experiments and two independent transfections. ${ }^{*} p<0.005$ vs insulin:basal ratio in pGL3-IRS2(-834). B EMSA analysis was done with Fao nuclear extract and a ${ }^{32} \mathrm{P}-$ labelled doublestranded oligonucleotide containing $\mathrm{C}$ at $\mathrm{nt}-765$ of the IRS2 promoter $(-765 \mathrm{C})$. Competition analysis was done in the presence of $-765 \mathrm{C}$ (lane 3) or $-765 \mathrm{~T}$ (lane 4) oligonucleotide, respectively. In lane 1 , the ${ }^{32} \mathrm{P}$-labelled probe was applied to the gel without prior incubation with nuclear extract. Shifted bands are indicated with arrows. Free, free probe. Data are representative of three similar experiments

Table 4. Comparison of clinical profiles for the $-765 C / T$ polymorphisms in $5^{\prime}$ UTR of IRS2 for normal control subjects

\begin{tabular}{llllll}
\hline & $C C$ & $C T$ & $T T$ & $p$ value $^{\mathrm{a}}$ & $\mathrm{b}^{\mathrm{b}} p$ \\
\hline$n$ (men/women) & $59(27 / 32)$ & $110(57 / 53)$ & $79(30 / 49)$ & & \\
Age $($ years $)$ & $78.0 \pm 8.5(\mathrm{n}=59)$ & $74.1 \pm 8.0(\mathrm{n}=110)$ & $76.2 \pm 8.7(\mathrm{n}=79)$ & 0.011 & \\
Height $(\mathrm{cm})$ & $154 \pm 9.0(n=58)$ & $156 \pm 9.0(n=110)$ & $153 \pm 8.7(n=77)$ & 0.081 & \\
Weight $(\mathrm{kg})$ & $50.2 \pm 9.2(n=58)$ & $52.3 \pm 9.8(n=110)$ & $50.0 \pm 11.5(n=78)$ & 0.252 & \\
$\mathrm{BMI}\left(\mathrm{kg} / \mathrm{m}^{2}\right)$ & $21.2 \pm 3.6(\mathrm{n}=58)$ & $21.4 \pm 3.2(\mathrm{n}=110)$ & $21.4 \pm 4.4(\mathrm{n}=77)$ & 0.950 & \\
$\mathrm{HbA}_{\mathrm{lc}}(\%)$ & $5.17 \pm 0.31(\mathrm{n}=59)$ & $4.96 \pm 0.42(\mathrm{n}=110)$ & $5.08 \pm 0.36(\mathrm{n}=79)$ & 0.003 & 0.006 \\
FPG $(\mathrm{mg} / \mathrm{dl})$ & $99 \pm 19(\mathrm{n}=45)$ & $91 \pm 14(\mathrm{n}=81)$ & $93 \pm 13(\mathrm{n}=59)$ & 0.027 & \\
\hline
\end{tabular}

${ }^{a} p$ values were obtained by one-way ANOVA

${ }^{\mathrm{b}} p$ values obtained by ANCOVA using age and sex as covariance.

that the two SNPs in the 5' UTR of IRS2 were not associated with the susceptibility to Type II diabetes mellitus.

Effect of $S N P(-765)$ and insulin responsive element (IRE) on the transcriptional activity of IRS2 in the presence or absence of insulin. Since the above-identified $\operatorname{SNP}(-765)$ was localised in the close proximity of the cis regulatory element (nt -758 to -749 ) and the $\mathrm{HbA}_{1 \mathrm{c}}$ level was higher in the control subjects with $C / C$ than those with $C / T$ and $T / T$, it should be possible that this SNP could have an effect on IRS2 expression. We therefore investigated whether the $\operatorname{SNP}(-765)$ affects the transcriptional activity of IRS2. IRS2-driven reporter activity in the construct bearing thymine at nt -765 , pGL3-IRS2(-765T), was approximately $\sim 80 \%$ of that of the plasmid containing cytosine at nt -765 , pGL3-IRS2(-834), in Fao cells (Fig. 7A) and
Data are presented in means $\pm \mathrm{SD}$

FPG, Fasting plasma glucose

HepG2 cells. Because the mRNA expression for IRS2 was suppressed by the increase in plasma insulin concentration in the ob/ob and lipodystrophic mice [27] as well as freshly isolated rat hepatocytes [27, 28], we also examined the effect of insulin on transcriptional activity of these constructs. When measured in Fao cells in the presence of insulin, pGL3-IRS2(-834) showed approximately 50\% suppression in IRS2driven reporter activity, compared with that in the absence of insulin (Fig. 7A). In contrast, pGL3IRS2(-765T) did not show insulin-mediated suppression in IRS2-driven reporter activity in Fao cells when compared with its non-stimulated transcriptional activity (Fig. 7A). EMSA analysis indicated that protein-DNA complex visualised by incubation of the 32P-labelled probe containing the partial footprint 1 sequence with Fao nuclear extract was efficiently abolished by the presence of excess unlabelled com- 
petitor oligonucleotides containing $\mathrm{C}$ at $\mathrm{nt}-765$, whereas those containing $\mathrm{T}$ at $\mathrm{nt}-765$ showed only weak competition (Fig. 7B). These results suggested that the $\operatorname{SNP}(-765 \mathrm{~T})$ resulted in the functional alteration on the transcription of IRS2 by affecting the binding between IRS 2 and protein(s) required for the transcriptional regulation.

We finally addressed whether the mutation introduced in the so-called "insulin-responsive element (IRE)" (5'-TGTTTTG-3'), identified in our study and elsewhere $[28,29]$ at nt -570 to -564 of the $5^{\prime}$ UTR of $I R S 2$, affects the basal promoter activity and/or insulin-mediated change in the promoter activity (if any) of IRS2. Disruption of the IRE heptanucleotide sequence by two-base pairs substitution (-570 5'TGTTTTG-3' -565) resulted in a decrease in the IRS2-driven reporter activities in the absence of insulin and ablated the insulin-induced suppression in Fao cells (Fig. 7A, panel C).

\section{Discussion}

By sequencing the $5^{\prime}$ UTR of human IRS2 a TATA box was located at $n t-2190$ to -2184 , a location further upstream than that apparent for such elements in most other genes [30]. The transcriptional activity of the plasmid pGL3-IRS2(-2399), which contains the TATA box of IRS2, was almost identical to that of pGL3-IRS2(-2116), which lacks the TATA box, suggesting that the human IRS 2 promoter could be functionally TATA-less. The human $I R$ [31] and mouse IRS1 [32] genes also seem to lack a typical TATA box as well as a CCAAT box in their 5' UTRs; these genes have therefore been suggested to function as housekeeping genes [33]. However, with the use of the TFSEARCH program, we identified several CCAAT boxes in the $5^{\prime}$ UTR of human IRS2, suggesting that the transcriptional properties of human IRS2 differ from those of the human IR and mouse IRSI gene.

We located $10 \mathrm{bp}$ sequence between $\mathrm{nt}-758$ and -749 in the identified footprint 1 region that is suggested to function as cis regulatory element and be involved in the positive regulation of IRS 2 . Supershift analysis showed that polyclonal antibodies to $\mathrm{Sp} 2$ or to $\mathrm{Sp} 3$ reduced the mobility of the protein-DNA complexes formed by the footprint 1 probe (Fig. 4A, arrowheads); polyclonal antibodies to either AP2, Sp1, Sp4, E2F, gut Krüppel-like factor (GKLF), or HSF had no effect on the migration of these complexes. These results indicated that the supershifted protein-DNA complexes contained Sp2 and Sp3. We suggest however, that the contributions of these two Sp proteins to the promoter activity associated with the footprint 1 region is relatively minor because an oligonucleotide containing the consensus GC box sequence did not compete with the footprint 1 probe in its interaction with nuclear proteins and the binding of neither the anti-Sp2 nor the anti-Sp3 antibodies resulted in a complete displacement of any of the three bands corresponding to the major DNA-protein complexes. Rather, we consider that the $37000 \mathrm{M}_{\mathrm{r}}$ protein identified by ultraviolet-induced cross-linking and Southwestern blot analyses potentially binds to this 10 -bp sequence, thereby functioning as a major regulatory protein in the transcription of $I R S 2$.

Insulin-regulated transcriptional control of IRS2 was also examined in this study in the context of the recent study describing the involvement of IRE of $I R S 2$ in the insulin-mediated suppression of IRS2 transcription [28]. Fao cells transfected with pGL3IRS2(-765T) did not show a decrease in the basal transcription of IRS2-driven reporter, however, preserved a transcriptional activity in the presence of insulin at a level similar with that observed without insulin (Fig. 7A). As a result, this plasmid, pGL3IRS2(-765T), abolished the insulin-mediated suppression of IRS2 transcriptional activity. These observations are in contrast with the above-mentioned study as well as our observation in which Fao cells transfected with a human IRS2 containing mutated IRE showed a decrease in the IRS2-driven reporter activity in the absence of insulin [28]. We suggest that this latter observation might be a primary reason for the apparent loss of insulin-mediated suppression of IRS2 transcriptional activity in the cells transfected with IRS 2 containing mutated IRE. In this context, IRE of IRS2 identified herein and the previous study might not contribute to the ability of IRS2 to mediate signals from insulin to suppress the transcription of IRS2 itself but would be involved in preserving the basal IRS 2 transcriptional activity. In contrast, the sequence surrounding nt -765 could rather be involved in the pathway which mediate the signals from insulin to suppress IRS2 transcription in these cells.

The mechanism by which $\operatorname{SNP}(-765 \mathrm{~T})$ altered the insulin-mediated regulation of IRS2 transcription is currently unclear; however, we showed by EMSA analysis that cytosine residue at nt -765 is indeed involved, whereas thymine residue at the same position is less involved, in the binding between IRS 2 and protein(s) required for the transcriptional regulation although the sequence surrounding nt $-765(-777$ 5'-CGGGCCGGGGCCTCCGCGGGAGGGGGA-3' -751) does not correspond at all with the consensus IRE motif. These results, together with the results of luciferase reporter assay, emphasize the importance of the residue nt -765 in the insulin-mediated transcriptional regulation of IRS2.

Given that hyperinsulinaemia leads to a down-regulation of IRS2 in the liver, which is associated with insulin resistance, the ablation of insulin-mediated suppression of IRS2 transcription shown by the SNP(-765T) should have beneficial roles in confronting the glucose tolerance in human subjects with insulin resistance. However, the allele frequencies for this 
SNP were not different between the diabetic and the control group. Such favourable effects were neither evident in our experiments comparing many metabolic parameters including BMI and HOMA between Japanese Type II diabetic patients with or without the $\operatorname{SNP}(-765 C / T)$. However, results in healthy control subjects, analysed at the same time in this study, could support the hypothesis that $\mathrm{T}$ allele at $\mathrm{nt}-765$ have some profitable effects in preserving the normal glucose concentration, as shown by the lower $\mathrm{HbA}_{1 \mathrm{c}}$ in subjects bearing thymine at this position.

In conclusion, we have cloned and sequenced the proximal $2.4-\mathrm{kb}$ of the $5^{\prime}$ flanking region of the human IRS 2 gene, and have identified the sequence, nt -758 to -749 , in footprint 1 that contribute to positive regulation of IRS 2 transcription. A $37000 \mathrm{M}_{\mathrm{r}}$ protein was shown to bind to this 10-bp sequence. We screened the $5^{\prime}$ UTR of human IRS2 and identified the SNPs $(-765 C / T$ and $-2062 T / C)$. These SNPs were not associated with Type II diabetes, however, the former was suggested to be involved in the insulin-mediated regulation in the transcriptional activity of IRS 2 .

Acknowledgements. We thank E. Maeda, H. Sakura and Y. Kanai for providing valuable suggestions during the experiments, and R. Mochizuki and S. Uesaka for their assistance with cell culture and genotyping. We are grateful to Dr. C.R. Kahn and Dr. E. Araki for providing Fao cells. This work was supported (M. Kasuga) by a Grant-in-Aid for Creative Basic Research (10NP0201) and a Grant-in-Aid for Millennium Genome Project from the Ministry of Education, Culture, Sports Science and Technology.

\section{References}

1. White MF (1998) The IRS-signaling system: a network of docking proteins that mediate insulin action. Mol Cell Biochem 182:3-11

2. O'Neill T, Craparo A, Gustafson T (1994) Characterization of an interaction between insulin receptor substrate 1 and the insulin receptor by using the two-hybrid system. Mol Cell Biol 14:6433-6442

3. Yenush L, Makati K, Smith-Hall J, Ishibashi O, Myers M, White M (1996) The Pleckstrin Homology domain is the principle link between the insulin receptor and IRS-1. J Biol Chem 271:24300-24306

4. Sawka-Verhelle D, Tartare-Deckert S, White M, Van Obberghen E (1996) Insulin receptor substrate-2 binds to the insulin receptor through its phosphotyrosine binding domain and through a newly identified domain comprising amino acids 591-786. J Biol Chem 271:5980-5983

5. He W, Craparo A, Zhu Y, O’Neill T et al. (1996) Interaction of insulin receptor substrate-2 (IRS2) with the insulin and insulin-like growth factor I receptors. Evidence for two distinct phosphotyrosine-dependent interaction domains within IRS2. J Biol Chem 271:11641-11645

6. Burks DJ, Wang J, Towery $\mathrm{H}$ et al. (1998) IRS pleckstrin homology domains bind to acidic motifs in proteins. J Biol Chem 273:31061-31067

7. Tamemoto H, Kadowaki T, Tobe K et al. (1994) Insulin resistance and growth retardation in mice lacking insulin receptor substrate-1. Nature 372:182-186
8. Araki E, Lipes M, Patti M-E et al. (1994) Alternative pathway of insulin signalling in mice with targeted disruption of the IRS-1 gene. Nature 372:186-190

9. Withers D, Gutierrez J, Towery H et al. (1998) Disruption of IRS2 causes type 2 diabetes in mice. Nature 391:900904

10. Terauchi Y, Iwamoto K, Tamemoto H et al. (1997) Development of non-insulin dependent diabetes mellitus in the double knockout mice with disruption of insulin receptor substrate-1 and beta cell glucokinase genes. Genetic reconstitution of diabetes as a polygenic disease. J Clin Invest 99:861-866

11. Almind K, Bjorbaek C, Vestergaard H, Hansen T, Echwald SM, Pedersen O (1993) Amino acid polymorphisms of insulin receptor substrate-1 in non-insulin-dependent diabetes mellitus. Lancet 342:828-832

12. Mori H, Hashiramoto M, Kishimoto M, Kasuga M (1998) Amino acid polymorphysms of the insulin receptor substrate-1 in Japanese non insulin dependent diabetes mellitus. J Clin Endocrinol Metab 80:2822-2826

13. Sun XJ, Wang LM, Zhang Y (1995) Role of IRS2 in insulin and cytokine signaling. Nature 377:173-177

14. Bernal D, Almind K, Yenush L (1998) IRS2 amino acid polymorphisms are not associated with random type 2 diabetes among Caucasians. Diabetes 47:976-979

15. Almind K, Frederiksen SK, Bernal D (1999) Search for variants of the gene-promoter and the potential phosphotyrosine encoding sequence of the insulin receptor substrate2 gene: evaluation of their relation with alterations in insulin secretion and insulin sensitivity. Diabetologia 42:12441249

16. Mammsrella S, Romano F, Varlerio AD (2000) Interaction between the G1057D variant of IRS-2 and overweight in the pathogenesis of type 2 diabetes. Hum Mol Genet $17: 2517-2521$

17. Vaßen L, Wegrzyn W, Klein-Hitpass L (1999) Human insulin receptor substrate-2. Gene organization and promoter characterization. Diabetes 48:1877-1880

18. Vaßen L, Wegrzyn W, Klein-Hitpass L (2000) Human insulin receptor substrate- 2 is a primary progesterone response gene. Mol Endocrinol13:485-494

19. Heinemeyer T, Wingender E, Reuter I (1998) Databases on transcriptional regulation: TRANSFAC, TRRD and COMPEL. Nucleic Acids Res 26:362-367

20. Heinemeyer T, Chen X, Karas H et al. (1999) Expanding the TRANSFAC database towards an expert system of regulatory molecular mechanisms. Nucleic Acids Res 27:318-322

21. Schreiber E, Matthias P, Müller MM, Schaffner W (1989) Rapid detection of octamer binding proteins with "miniextracts", prepared from a small number of cells. Nucleic Acids Res 17:6419

22. Laemmli UK (1970) Cleavage of structural proteins during the assembly of the head of bacteriophage T4. Nature 227:680-685

23. Mori H, Ikegami H, Seino S et al. (2000) The Met416 $\rightarrow$ Val variant in the Glycogen Synthase Gene: The prevalence and the association with diabetes in a large number of Japanese individuals. Diabetes Care 23:1709-1710

24. Mori H, Ikegami H, Kawaguchi Y et al. (2001) The Pro12Ala substitution in PPAR- $\gamma$ is associated with resistance to development of diabetes in the general population: Possible involvement in impairment of insulin secretion in individuals with type 2 diabetes. Diabetes 50:891-894

25. World Health Organization (1985) Diabetes Mellitus: Report of a WHO Study Group. Technical Report Series No 727 World Health Organisation, Geneva 
26. Matthews DR, Hosker JP, Rudenski AS, Naylor BA, Treacher DF, Turner RC (1985) Homeostasis model assessment: insulin resistance and $\beta$-cell function from fasting plasma glucose and insulin concentration in man. Diabetologia 28:412-419

27. Shimomura I, Matsuda M, Hammer RE, Bashmokov Y, Brown SM, Goldstein JL (2000) Decreased IRS-2 and increased SREBP-1c lead to mixed insulin resisyance and sensitivity in lives of lipodystrophic and ob/ob mice. Mol Cell 6:77-86

28. Zhang J, Ou J, Bashmokov Y, Horton JD, Brown MS, Goldstein JL (2001) Insulin inhibits transcription of IRS-2 gene in rat liver through an insulin response element (IRE) that resembles IREs of other insulin repressed genes. Proc Natl Acad Sci USA 98:3756-3761
29. O'Brien RM, Granner DK (1996) Regulation of gene expression by insulin. Physiol Rev 76:1109-1161

30. Breathnach R, Chambon P (1981) Organization and expression of eucaryotic split genes coding for proteins. Annu Rev Biochem 50:349-383

31. Cameron KE, Resnik J, Webster NJ (1992) Transcriptional regulation of the human insulin receptor promoter. J Biol Chem 267:17375-17383

32. Araki E, Haag BL, Matsuda K, Shichiri M, Kahn CR (1995) Characterization and regulation of the mouse insulin receptor substrate gene promoter. Mol Endocrinol 9:1367-1379

33. Slansky JE, Farnhm PJ (1996) Transcriptional regulation of the dihydrofolate reductase gene. Bioessays 18:55-62 